\title{
Zonal expression of the thyroid hormone receptor $\alpha$ isoforms in rodent liver
}

\author{
B Zandieh-Doulabi, E Dop ${ }^{1}$, M Schneiders, M P-T Schiphorst, \\ A Mansen ${ }^{2}$, B Vennström², C D Dijkstra ${ }^{1}$, O Bakker and \\ W M Wiersinga
}

\author{
Department of Endocrinology and Metabolism, Academic Medical Centre, F5-171, Meibergdreef 9, 1105 AZ Amsterdam, The Netherlands \\ ${ }^{1}$ Department of Molecular Cell Biology, VU Medical Centre, Amsterdam, The Netherlands \\ ${ }^{2}$ Laboratory of Developmental Biology, Department of Cell and Molecular Biology (CMB), Karolinska Institute, S-171 77 Stockholm, Sweden \\ (Requests for offprints should be addressed to O Bakker; Email: o.bakker@amc.uva.nl)
}

\begin{abstract}
Many metabolic processes occur simultaneously in the liver in different locations along the porto-central axis of the liver units. These processes are often regulated by hormones, one of which is thyroid hormone which for its action depends on the presence of the different isoforms of the thyroid hormone receptor (TR). These are encoded by two genes: c-erbA- $\alpha$ encoding TR $\alpha 1$ and TR $\alpha 2$ and their respective $\Delta$ isoforms, and c-erbA- $\beta$ which encodes $\operatorname{TR} \beta 1, \operatorname{TR} \beta 2$ and TR $\beta 3$. We recently found a zonal (pericentral) expression of and a diurnal variation in the TR $\beta 1$ isoform in rat liver. We were therefore also interested to see whether TR $\alpha 1$ and TR $\alpha 2$ expression showed similar characteristics. For this reason we raised both polyclonal and monoclonal antibodies against TR $\alpha 1$ and TR $\alpha 2$ isoforms and characterised these. Antibody specificity was tested using Western blots and immuno-
\end{abstract}

histochemistry in liver of TR isoform-specific knockout animals. Using these antibodies we found that the TR $\alpha 1$ and TR $\alpha 2$ isoforms are zonally expressed around the central vein in rat liver. The experiments show that the portal to central gradient of TR $\alpha 1$ is broader than that of TR $\beta 1$. Moreover, the expression of the TR $\alpha 2$ protein showed a diurnal variation with a peak in the afternoon when the animals are least active whereas no such variation was found for the TR $\alpha 1$ protein.

From our data it appears that both the TR $\alpha 1$ and TR $\alpha 2$ isoforms show a zonal distribution in liver. This finding, together with the observed diurnal rhythm, has major implications for interpreting and timing experiments concerning the TR and its downstream actions in liver. Journal of Endocrinology (2003) 179, 379-385

\section{Introduction}

In the liver many metabolic processes occur simultaneously, but not all of them take place in every liver parenchymal cell. Instead, the various metabolic reactions occur in different locations along the porto-central axis of the liver units (Klinger et al. 1988, Jungermann \& Katz 1989). For instance, lipolysis and glycolysis are predominant in liver cells around the central vein, whereas lipogenesis and gluconeogenesis are found in the area around the portal vein. This so-called metabolic zonation can be of a stable or dynamic kind which means that the expression of certain enzymes is either restricted to certain cells regardless of the metabolic or hormonal state, or the expression of the enzymes can expand or shrink along the porto-central axis depending on the metabolic state or time of the day. Enzymes with a stable distribution can be located pericentrally (like glutamine synthetase) or periportally (like fructose 1,6-bisphosphatase (Eilers et al.
1995)). Similarly, enzymes with a dynamic distribution can be located pericentrally (ornithine aminotransferase (Swick et al. 1970)) or periportally (phosphoenolpyruvate carboxy-kinase, PEPCK (Bartels et al. 1990)).

Thyroid hormone has many diverse actions in the body. These actions depend on the presence of the different isoforms of the thyroid hormone receptor (TR) (Yen 2001). Thyroid hormone receptors belong to the nuclear receptor superfamily and act mainly as transcription factors. They are encoded by two separate genes: c-erbA- $\alpha$ which encodes TR $\alpha 1$ and TR $\alpha 2$ and their respective $\Delta$ isoforms, and c-erbA- $\beta$ which encodes TR $\beta 1, \operatorname{TR} \beta 2$ and TR $\beta 3$ isoforms. Thyroid hormone (triiodothyronine, $\mathrm{T}_{3}$ ) signals its presence to the cell by binding to these TRs which then interact with so-called thyroid hormone response elements in the promoter of $\mathrm{T}_{3}$-responsive genes and thereby activate or repress genes. TRs are differentially distributed in various tissues and during developmental stages, indicating distinct or specific functional 
roles. TR $\alpha 1$ and TR $\alpha 2$ are mainly present in the central nervous system and muscle whereas TR $\beta 1$ is predominantly present in the liver. Studies using knockout mice have shown that certain actions of thyroid hormone are dependent on a particular receptor isoform (Amma et al. 2001) and the expression patterns of some of these genes overlap with that of the TR $\beta 1$ isoform they depend on $(\mathrm{H}$ Gulberg, B Zandieh-Doulabi, D Forrest, O Bakker, B Vennström, unpublished observations).

We recently found a zonal (pericentral) expression of and a diurnal variation in the TR $\beta 1$ isoform in rat liver (Zandieh Doulabi et al. 2002). Therefore, we were interested to see whether TR $\alpha 1$ and TR $\alpha 2$ expression showed similar characteristics. For this reason we raised antibodies against the TR $\alpha 1$ and TR $\alpha 2$ isoforms. We generated polyclonal and monoclonal antibodies against the TR $\alpha$ isoforms and characterised these. We tested antibody specificity using Western blots and immunohistochemistry in liver of TR isoform-specific knockout animals.

\section{Materials and Methods}

Wistar rats (Harlan Sprague Dawley, Zeist, The Netherlands) were kept in a $12 \mathrm{~h}$ light/12 h darkness cycle with free access to food. All animal experiments were approved by our local Animal Welfare Committee. Lights were switched on at $0700 \mathrm{~h}$. The liver of each animal was used for immunohistochemistry and Western blots.

\section{Polyclonal antibodies}

To produce anti-TR antisera, two linear synthetic peptides coupled to keyhole limpet haemocyanin $(\mathrm{KLH})$ were made, namely amino acids 402-410 $\left(\mathrm{NH}_{2}\right.$-EVFEDQEV$\mathrm{COOH})$ for human TR $\alpha 1$, and amino acids 425$442\left(\mathrm{NH}_{2}-\mathrm{SLR} G P V L Q H Q S P K S P Q Q R-\mathrm{COOH}\right)$ for TR $\alpha 2$. Using these peptides antisera were raised in New Zealand White rabbits and affinity purified by Eurogentec (Seraing, Belgium).

\section{Monoclonal antibodies}

The same KLH-conjugated linear synthetic peptides TR $\alpha 1$ and TR $\alpha 2$ described above were used for immunisations in mice with a total of four injections of $25 \mu \mathrm{g}$ peptide each. The first injection (subcutaneously in complete Freund's adjuvant) was seven weeks before death, the second and third injections (intraperitoneally in complete Freund's adjuvant) were respectively two and four weeks after the first injection and finally the last injection was given intravenously. Five days after the last boost of immunisation, the spleen cells from the immunised BALB/C mice were fused with myeloma (SP20) by means of polyethylene glycol 1500 (Roche Molecular Biochemicals-Germany). The fused cells were plated on 24-well plates in hypoxanthine aminopetrine thymidine (HAT)-DMEM $/ 15 \%$ FCS $/ 1 \%$ PenStrep (Sigma) in the presence of $5 \%$ hybridoma cloning factor (HCF; Sanvertech, Breda, The Netherlands). Fourteen days later the supernatants of the hybridomas were screened by immunohistochemistry. Positive clones were subcloned in 96-well plates in HAT medium by limiting dilution. The supernatants from the positive subcloned hybridomas were used for further screening on the liver of a rat killed at $1930 \mathrm{~h}$ and in nuclear or whole cell extracts on Western blots.

The selected clones were grown in bulk. The supernatant of each monoclonal antibody was precipitated with half the starting volume of saturated ammonium sulphate (Merck, Darmstad, Germany), which was added dropwise and was then left stirring overnight at $4{ }^{\circ} \mathrm{C}$. The next morning after centrifugation at $3000 \mathrm{~g}$ for $30 \mathrm{~min}, 20 \mathrm{ml}$ ammonium sulphate were added at $4{ }^{\circ} \mathrm{C}$ for $6 \mathrm{~h}$. After centrifugation for $30 \mathrm{~min}$ at $3000 \mathrm{~g}$, the pellet was saved and dissolved in 0.1 volume $(4 \mathrm{ml})$ of PBS. The concentrated antibody was dialysed overnight at $4{ }^{\circ} \mathrm{C}$ in a dialysis tube (cut-off $12000 \mathrm{M}$.W., Thomas, USA).

A mouse monoclonal antibody isotyping kit (Hycult Biotechnology, Uden, The Netherlands) was used to establish the isotype of the monoclonal antibodies.

\section{Western blots}

Whole cell extracts (WCE) from livers were prepared by homogenising in $0.25 \mathrm{M}$ sucrose containing complete protease inhibitor (Roche Molecular Biochemicals) using a homogeniser for $10 \mathrm{~s}$ at maximum speed. Protein concentration of the WCE was determined using Biorad reagent (Biorad, Germany). Subsequently, $25 \mu \mathrm{g}$ protein were loaded on 10\% SDS-PAGE gel. After electroblotting onto membrane (Protran BA45, Schleicher \& Schuell, Dassel, Germany), the blots were blocked for $45 \mathrm{~min}$ in Trisbuffered saline (TBS) containing 1\% (w:v) caseine (Roche, Germany) and 0.1\% (w:v) Tween 20 (blocking buffer). Next, the blots were incubated for $2 \mathrm{~h}$ at $22{ }^{\circ} \mathrm{C}$ with the primary antiserum (polyclonal antisera, 1:250 dilution and monoclonal antisera, 1:50 dilution). After $30 \mathrm{~min}$ incubation with secondary antibodies (1:20 000 dilution) in blocking buffer, the blots were washed and Lumilight ${ }^{\text {Plus }}$ substrate (Roche Molecular Biochemicals) was added. The signals were visualised and quantified using a Lumilmager (Roche Molecular Biochemicals).

Nuclei were isolated as previously described (Wiersinga et al. 1982). In short, $4 \mathrm{~g}$ liver were homogenised in Sol A (20 mM Tris. $\mathrm{HCl}, 0.25 \mathrm{M}$ sucrose, $2 \mathrm{mM} \mathrm{CaCl}, 1 \mathrm{mM}$ $\mathrm{MgCl}_{2}$, and 5\% (v/v) glycerol, $\left.\mathrm{pH}=7 \cdot 6\right)$. The nuclei were pelleted by ultracentrifugation $(45000 \mathrm{~g}$ for $45 \mathrm{~min}$ at $4{ }^{\circ} \mathrm{C}$ ) and washed with Sol A containing 0.5\% Triton $\mathrm{X}-100$ and resuspended in Sol B (200 mM Tris, 5\% (v/v) glycerol, $0.25 \mathrm{M}$ sucrose, $1 \mathrm{mM}$ EDTA and $50 \mathrm{mM}$ $\mathrm{NaCl}$ ) and stored in liquid nitrogen. The amount of 
protein in this nuclear preparation was determined using the Biorad protein assay. For Western blots $50 \mu \mathrm{g}$ protein equivalent of nuclei were used.

\section{Immunohistochemistry}

Both paraffin-embedded and frozen livers of several rats were used as tissue for immunohistochemistry. The frozen rat liver sections of $6 \mu \mathrm{m}$ were fixed with different kinds of fixatives depending on the type of experiments: paraformaldehyde (PFA; (Merck, Germany) 4\% (w:v) in phosphate-buffered saline (PBS); $\mathrm{pH}=7 \cdot 4)$, acetone, methanol or ethanol for $15 \mathrm{~min}$ at $4{ }^{\circ} \mathrm{C}$. Paraffinembedded rat livers were fixed for $16 \mathrm{~h}$ at $4{ }^{\circ} \mathrm{C}$ in PFA sections $(6 \mu \mathrm{m})$ and pasted on Superfrost/Plus (MenzelGläser, Germany) slides and dewaxed prior to immunostaining.

Sections were placed in TBS $(\mathrm{pH}=8 \cdot 0)$ and microwaved for $10 \mathrm{~min}$ for the paraffin and $5 \mathrm{~min}$ for the frozen sections to unmask the antigenic epitope. After cooling to room temperature, the sections were placed in a blocking solution for $60 \mathrm{~min}$ (5\% low fat milk (Campina, The Netherlands) and a detergent, either 0.1\% (w:v) Triton X-100 (Sigma) or $0.5 \%$ (w:v) saponin (Sigma) diluted in TBS at $\mathrm{pH}=8 \cdot 0)$. The first antibodies were diluted in the blocking solution, and incubated first for $1 \mathrm{~h}$ at room temperature and then overnight at $4{ }^{\circ} \mathrm{C}$. The sections were washed with $0.5 \%(\mathrm{w}: \mathrm{v})$ Triton X-100 in TBS $(\mathrm{pH}=8 \cdot 0)$ for $10 \mathrm{~min}$, and then incubated with the second antibody (conjugated with alkaline phosphatase) diluted with $0.5 \%(\mathrm{w}: \mathrm{v})$ Triton $\mathrm{X}-100$ in TBS $(\mathrm{pH}=8 \cdot 0)$. After a washing period of $10 \mathrm{~min}$ in TBS, the sections were placed in alkaline phosphatase buffer $(50 \mathrm{mM} \mathrm{MgCl}, 100 \mathrm{mM}$ $\mathrm{NaCl}$, and $100 \mathrm{mM}$ Tris, $\mathrm{pH}=9 \cdot 2)$ for $10 \mathrm{~min}$. The substrates NBT/BCIP (Roche Diagnostics, Germany) and 0.1 M levamisole (Sigma) were diluted respectively 1:50 and 1:100 in alkaline phosphatase buffer and added to the sections for $30 \mathrm{~min}$ to $90 \mathrm{~min}$ in the dark. The sections were washed in TBS and then placed in methanol (Merck) for at least $5 \mathrm{~min}$ to reduce background. The sections were enclosed with Kaiser's glycerol gelatine (Merck).

\section{Data analysis}

Differences between time points ( $n=6$ per time point) in the Western blots were evaluated using the nonparametric Mann-Whitney U test. Data are presented as means \pm S.D

The experiments designed to evaluate the optimal $\mathrm{pH}$ for incubation (see Results) were repeated twice. The staining intensity of each section was then judged by two blinded observers who could give the following marks for staining intensity: 0 , no staining; 1, weak staining; 2 , intense staining; 3, very intense staining. Results of the two observers were averaged and plotted.

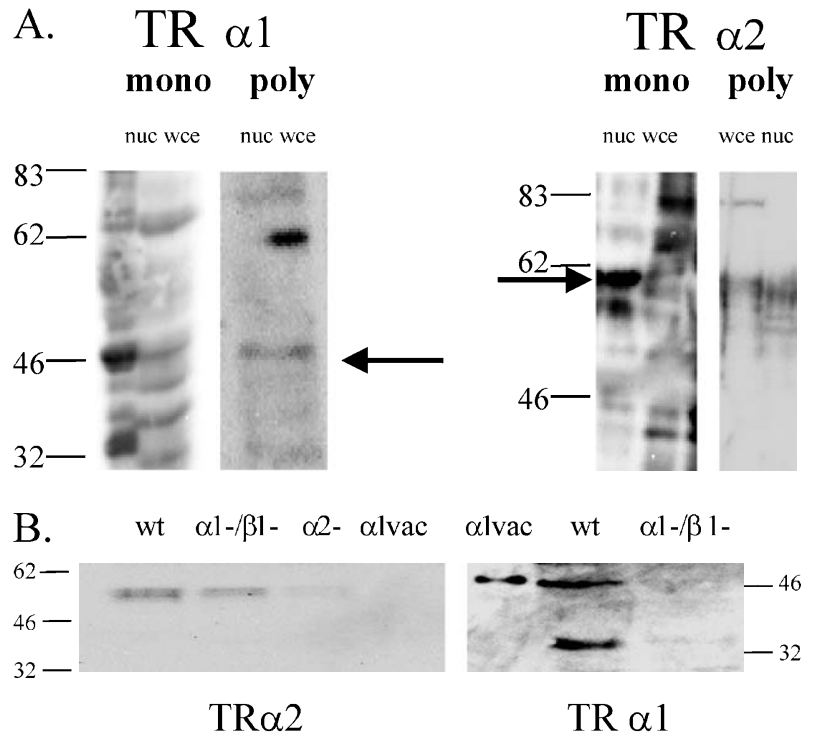

Figure 1 Specificity of the TR $\alpha 1$ and TR $\alpha 2$ antibodies tested on Western blots. (A) Western blots were prepared using both nuclear (nuc) and whole cell extracts (wce). These were incubated with either the TR $\alpha 1$ or TR $\alpha 2$ monoclonal or polyclonal antibodies as described in Materials and Methods. The arrow indicates the specific bands. Position of the protein size markers is indicated alongside. (B) Western blots were prepared with whole cell extracts from wild-type (wt), TR $\alpha 1^{-/-} / \beta 1^{-/-}(\alpha 1-/ \beta 1-)$ and TR $\alpha 2^{-1-}(\alpha 2-)$ mice and Vaccinia-expressed TR1 $\alpha 1$ ( $\alpha 1 \mathrm{vac}$ ). These blots were incubated with the polyclonal antibodies against TR $\alpha 1$ and TR $\alpha 2$ to check specificity. Position of the protein size markers is indicated alongside.

\section{Results}

\section{Specificity of antibodies on Western blots}

Polyclonal TR $\alpha 1$ and TR $\alpha 2$ antibodies The polyclonal antibodies were typed as IgG type antibodies. In liver WCE and nuclear extracts a $47 \mathrm{kDa}$ band was detected using the TR $\alpha 1$ polyclonal antiserum and a $58 \mathrm{kDa}$ band was detected using the TR $\alpha 2$ polyclonal antiserum (Fig. 1A). As a control for the TR $\alpha 1$ polyclonal antiserum we used a Vaccinia-expressed TR $\alpha 1$. We also tested both our polyclonal antibodies on Western blots of liver WCE of animals where either the TR $\alpha 1$ or TR $\alpha 2$ was knocked out (Wikstrom et al. 1998, Ng et al. 2001). The TR $\alpha 1$ polyclonal antibody showed no signal at $47 \mathrm{kDa}$ in liver WCE from a TR $\alpha 1^{-/-} / \mathrm{TR} \beta 1^{-/-}$animal and the TR $\alpha 2$ polyclonal antibody did not show the $58 \mathrm{kDa}$ band which was seen in the wild-type animals (Fig. 1B). Furthermore no cross-reaction with TR $\alpha 1$ protein is found, since Vaccinia-TR $\alpha 1$ was not detected with this antibody (Fig. 1B).

The specificity of the antisera was further supported by negative pre-immune serum staining and by negative staining with antiserum preadsorbed with antigenic 


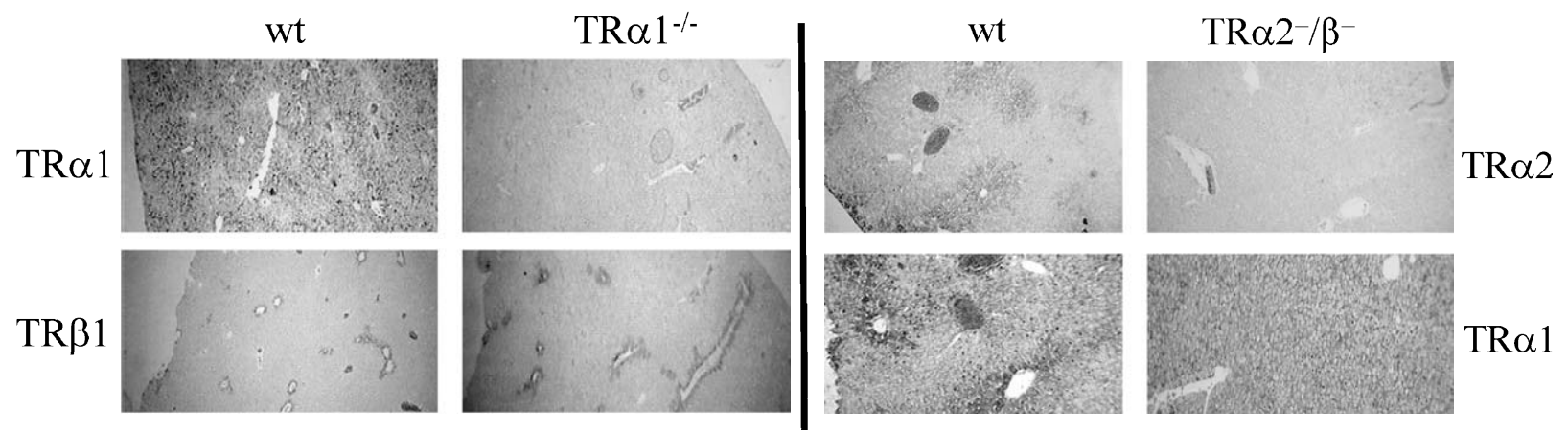

Figure 2 Specificity of the TR 1 and TR $\alpha 2$ antibodies tested with immunohistochemistry. (Left panel) Slices from livers of wild-type (wt) or TR $\alpha 1^{-1-}$ mice were incubated with the monoclonal TR $\alpha 1$ antibody with the TR $\beta 1$ polyclonal as a control. (Right panel) The monoclonal TR $\alpha 2$ antibody was incubated with slices from livers of wild-type (wt) and TR $\alpha 2^{-/-} / \beta 1^{-/-}$mice using the TR 1 polyclonal antibody as a control. Magnification $\times 40$.

peptide. Isoform specifity was also supported by the absence of cross-reactivity as examined by immunocytochemical staining of the TR peptides TR $\alpha 1$ (amino acids (aa) 402-410), TR $\alpha 2$ (aa 425-442), TR $\beta 1$ (aа 74-92) and TR $\beta 2$ (aa 131-145) fixed on nitrocellulose membrane.

Monoclonal TRa1 and TRa2 antibodies The monoclonal antibody clones were typed as IgM. The specificity of the monoclonal antibodies was tested on liver slices derived from mice lacking either $\operatorname{TR} \alpha 1\left(\operatorname{TR} \alpha 1^{-/-}\right)$or $\operatorname{TR} \alpha 2\left(\operatorname{TR} \alpha 2^{-I^{-}} / \beta 1^{-{ }^{-}}\right)$. As can be seen in Fig. 2 no staining was observed with the TR $\alpha 1$ monoclonal antibody in a TR $\alpha 1^{-/-}$liver. This was not a general loss of TR since the TR $\beta 1$ polyclonal antibody was still able to detect the TR $\beta 1$ protein in the pericentral cells in the TR $\alpha 1^{-\prime-}$ animals (Fig. 2). TR $\alpha 2$ staining was absent in the TR $\alpha 2^{-\prime-} / \mathrm{TR} \beta 1^{-\prime-}$ animals. In these mice TR $\alpha 1$ was detected in a control experiment and found to be broader than in the wild-type mice. On Western blots the monoclonal TR $\alpha 1$ antibodies detected bands of similar size $(47 \mathrm{kDa})$ to those detected with the polyclonal antibody but the signal was stronger in the nuclear preparation. With the TR $\alpha 2$ monoclonal antibody, a strong band of about $58 \mathrm{kDa}$ was detected in the nuclear preparation at the same position as the bands found with the polyclonal TR $\alpha 2$ antibody.

As with the polyclonal antibodies, isoform specifity was also supported by the absence of cross-reactivity as examined by immunocytochemical staining of the fixed TR peptides TR $\alpha 1$, TR $\alpha 2$, TR $\beta 1$ and TR $\beta 2$ on nitrocellulose membrane.

\section{Immunohistochemistry}

In order to study the distribution of the TR $\alpha 1$ and $\alpha 2$ proteins in liver we set out to determine the optimal incubation conditions for our antibodies. The parameters of interest are microwave treament before incubation with the first antibody, salt $(\mathrm{NaCl})$ concentration and $\mathrm{pH}$ during the first antibody incubation. When performing immunohistochemistry on both frozen and paraffin embedded sections of the rat liver we found that microwave treatment diminished background and intensified staining (probably by unmasking the antigenic epitope) with both polyclonal and monoclonal antibodies on sections fixed with PFA. We therefore used PFA as fixative and microwave treatment in all immunohistochemistry experiments using both polyclonal and monoclonal antibodies.

To find the optimum salt concentration during incubation with the first antibody at $\mathrm{pH} 8$ we performed experiments with both frozen and paraffin embedded sections by increasing the salt concentration from $0 \mathrm{mM}$ to $600 \mathrm{mM} \mathrm{NaCl}$. Increasing the $\mathrm{NaCl}$ concentration up to $400 \mathrm{mM}$ had no effect on the staining in the case of both polyclonal and monoclonal TR $\alpha 2$. Surprisingly, the TR $\alpha 1$ monoclonal antibodies were very sensitive to an increase in the $\mathrm{NaCl}$ concentration. Since all different antibodies stained well at $150 \mathrm{mM} \mathrm{NaCl}$ this concentration was chosen in further experiments. Using this $150 \mathrm{mM} \mathrm{NaCl}$ concentration we next determined the $\mathrm{pH}$ optimum during incubation with the first antibody. For the TR $\alpha 1$ and TR $\alpha 2$ polyclonal antibodies and the TR $\alpha 2$ monoclonal antibody the $\mathrm{pH}$ optimum was around $\mathrm{pH} 8$. However, for the monoclonal TR $\alpha 1$ antibody the $\mathrm{pH}$ optimum was around pH 5 (Fig. 3).

Since the monoclonal TR $\alpha 1$ antibody had a lower $\mathrm{pH}$ optimum we determined optimum salt concentration for this antibody at this $\mathrm{pH}$ and we found again that the antibody was very sensitive to the $\mathrm{NaCl}$ concentration. Moreover, at this $\mathrm{pH}$ background was reduced using saponin in the incubation mixture.

Taking these results together we decided to use the monoclonal antibodies in the experiments aimed at studying the distribution and diurnal rhythm of the TR $\alpha$ isoforms. In these experiments the TR $\alpha 1$ monoclonal antibodies were diluted 1:50 in blocking buffer, $0 \cdot 5 \%$ (w:v) saponin, $\mathrm{pH} 5$ with no additional salt and the TR $\alpha 2$ 


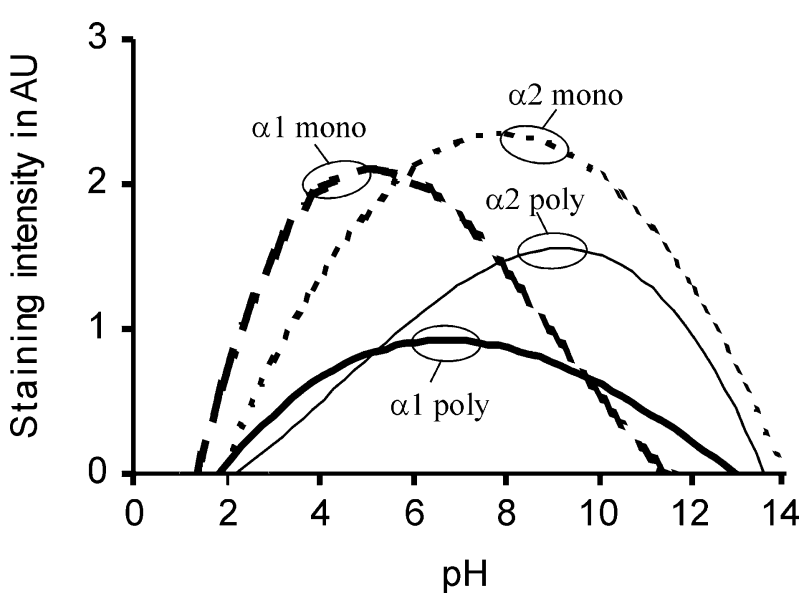

Figure $3 \mathrm{pH}$ dependence of the antibody reaction in immunohistochemistry. The signal intensity of the immunostaining measured in arbitrary units (AU) is indicated as a function of the $\mathrm{pH}$ of the incubation medium (see Materials and Methods). The curves of the individual antibodies are indicated in the figure by a circle and a name.

monoclonal antibodies were diluted 1:50 in blocking buffer $\mathrm{pH} 8$ with $150 \mathrm{mM} \mathrm{NaCl}$.

\section{Zonal distibution}

Immunohistochemistry using the monoclonal antibodies on liver sections indicated that TR $\alpha 1$ and TR $\alpha 2$ were expressed around the central veins (Fig. 4). This expression pattern overlaps with that of the TR $\beta 1$ (ZandiehDoulabi et al. 2002) and with the centrally expressed, $\mathrm{T}_{3}$-responsive gene glutamine synthetase (GS), which we stained as a control on consecutive sections. However, the area of expression of the TR $\alpha 1$ and TR $\alpha 2$ proteins extends further along the porto-central axis then that of TR $\beta 1$ and GS.

\section{Diurnal variation of TRa isoforms in rat liver}

When rats were killed at different time points during the day we found different staining intensities for the TRas in liver slices. Especially, TR $\alpha 2$ expression differed when the rats were killed in the morning compared with those killed in the afternoon. These results were confirmed using Western blotting where it can be seen that no change in expression level of TR $\alpha 1$ is found (Fig. 5A) but that there is a marked diurnal variation in the expression of the TR $\alpha 2$ protein (Fig. 5B) with a peak during the afternoon when the animals are least active. Immunohistochemistry showed that the expression of both TR $\alpha 1$ and TR $\alpha 2$ was of a stable kind.

\section{Discussion}

Here we report the generation of a set of antibodies, both polyclonal and monoclonal, directed against the thyroid

\section{rat}
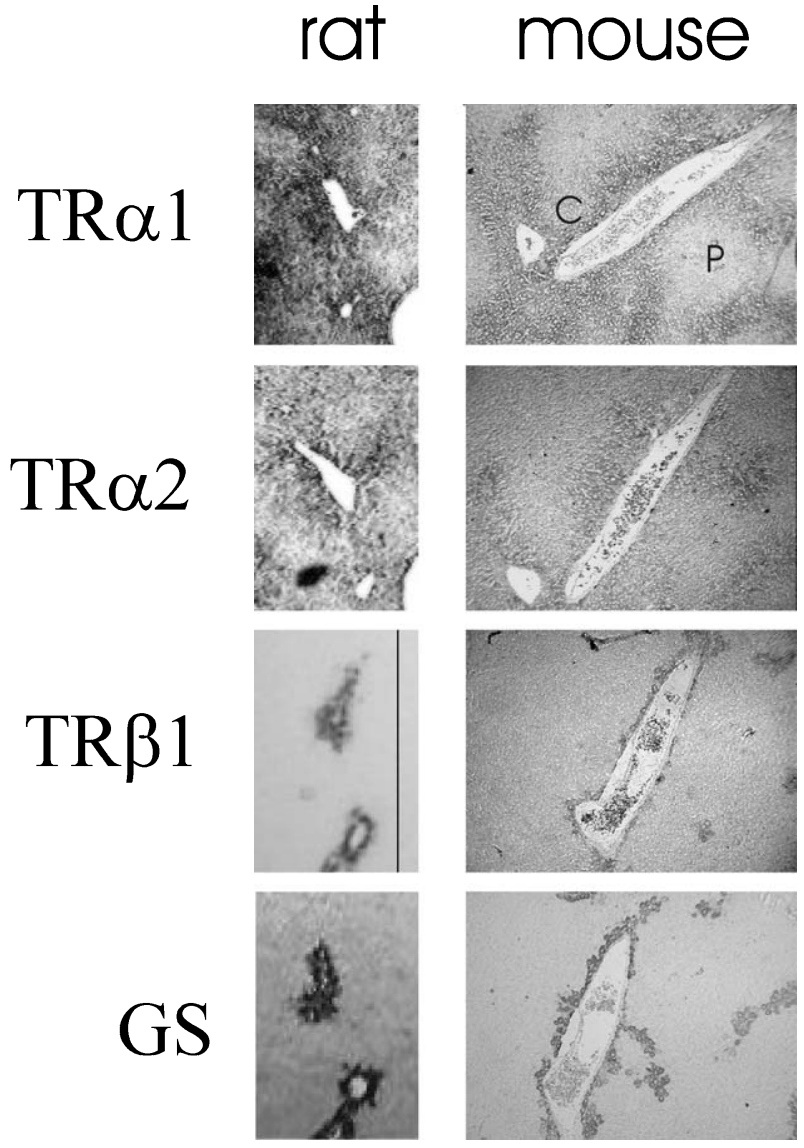

Figure 4 Zonal expression of the TR $\alpha 1$, TR $\alpha 2$ and TR $\beta 1$ isoforms. Rat or mouse liver slices were incubated with the monoclonal antibodies directed against TR $\alpha 1$ and TR $\alpha 2$ and the polyclonal anti-TR $\beta 1$. Monoclonal anti-glutamine synthetase (GS) was used as a control to identify the central veins. Magnification $\times 100$.

hormone receptor $\alpha 1$ and $\alpha 2$ isoforms which are specific for these isoforms according to the criteria used by us (Western blots with wild-type and specific knockout WCE and staining on slices of wild-type and specific knockout livers). Since the monoclonal antibodies gave a better signal on the Western blots we performed our studies on the zonal distribution and the diurnal variation of the TR $\alpha 1$ and $\alpha 2$ isoforms with the monoclonal antibodies.

Several immunohistochemical studies have reported the presence of TR proteins in the liver of rodents and humans (Tagami et al. 1990, Strait et al. 1991, Macchia et al. 1992, Rodd et al. 1992, Falcone et al. 1994). Although not all hepatocytes were stained in these studies, none of these studies mention a topographical distribution of TR isoforms even though most known $\mathrm{T}_{3}$-dependent genes are expressed in the liver in different zones. We showed recently that the TR $\beta 1$ protein was expressed in a rather small area around the central vein of rat liver and that its expression varies during the day (Zandieh-Doulabi et al. 2002). Moreover, certain TR $\beta 1$-dependent genes, for 


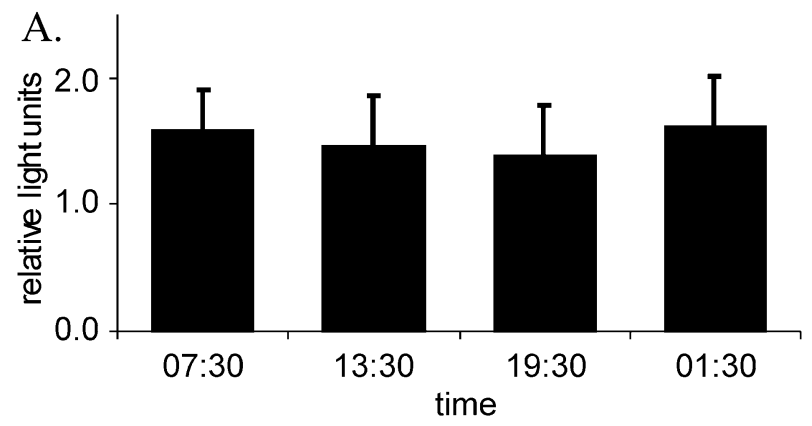

B. $\quad \mathrm{p}<0.05$

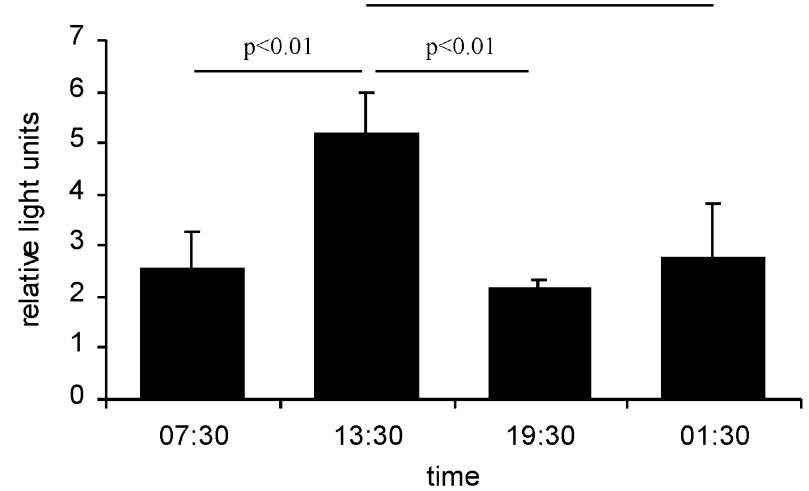

Figure 5 Diurnal variation of the TR $\alpha 1$ and TR $\alpha 2$ isoform proteins. The figure shows the signal intensities (expressed relative to an internal standard) derived from Western blots of whole cell extracts of rat liver incubated with monoclonal TR $\alpha 1$ (A) or monoclonal TR $\alpha 2$ (B). Rats were killed (6 per time point) at the time points indicated in the figure. Lights were on from $0700 \mathrm{~h}$ to 1900 h. Data are expressed as means \pm S.D. and significant differences (Mann-Whitney $U$ test), when present, are indicated.

example the low density lipoprotein-receptor or CYP7a (Gullberg et al. 2002) are expressed in the same area. Here we show that a similar stable zonal expression exists for two other TR isoforms, TR $\alpha 1$ and TR $\alpha 2$. Although these two isoforms are also expressed around the central vein, the extent of the zonal expression for both TR $\alpha$ isoforms is wider then that of the TR $\beta 1$. Interestingly, the TR $\alpha 1$ expression gets even broader in the TR $\alpha 2^{-/-} / \mathrm{TR} \beta 1^{-/-}$mice probably as a result of the overexpression of TR $\alpha 1$ in these mice ( $\mathrm{Ng}$ et al. 2001).

Our findings suggest the possibility that there may be genes solely dependent on TR $\alpha 1$ or TR $\beta 1$ whereas there will be another set which is specifically activated by one of the isoforms depending on its localisation along the portocentral axis of the liver unit. For instance, CYP7a is expressed mainly in the pericentral zone in conjunction with all receptors (Berkowitz et al. 1995, Brassil et al. 1995, Massimi et al. 1998) while a gene encoding PEPCK, for example, is expressed towards the periportal zone where the TR as are present. Therefore, based on the localisation of PEPCK it can be suggested that TR $\alpha 1$ is the most likely candidate to confer $\mathrm{T}_{3}$ regulation on this gene.
From our results it is apparent that the expression of TR $\alpha 2$ shows a diurnal rhythm whereas that of TR $\alpha 1$ does not. This hints at the possibility of regulated splicing, a phenomenon known to occur in other systems (NissimRafinia \& Kerem 2002, Perrone-Bizzozero \& Bolognani 2002). The diurnal expression of the TR $\beta 1$ protein is the reverse of that of the TR $\alpha 2$ protein, with maximum TR $\beta 1$ protein expression observed at the beginning of the dark period when the rats are nutritionally active.

Whether the rhythm is dependent on the suprachiasmatic clock or on food intake is at present unknown but the presence of a rhythm in the serum levels of thyroid hormones and in the expression of the TR isoforms together with the knowledge that thyroid hormone regulates many genes (especially metabolic ones) in liver (Feng et al. 2000) points to the fact that thyroid hormone may play a role in mediating the clock signal originating in the suprachiasmatic nucleus.

\section{Funding}

This work was supported by grant 903-40-194 from The Netherlands Organisation for Scientific Research (NWO).

\section{References}

Amma LL, Campos-Barros A, Wang Z, Vennstrom B \& Forrest D 2001 Distinct tissue-specific roles for thyroid hormone receptors $\beta$ and $\alpha$ in regulation of type 1 deiodinase expression. Molecular Endocrinology 15 467-475.

Bartels H, Herbort H \& Jungermann K 1990 Predominant periportal expression of the phosphoenolpyruvate carboxykinase and tyrosine aminotransferase genes in rat liver. Dynamics during the daily feeding rhythm and starvation-refeeding cycle demonstrated by in situ hybridization. Histochemistry 94 637-644.

Berkowitz CM, Shen CS, Bilir BM, Guibert E \& Gumucio JJ 1995 Different hepatocytes express the cholesterol 7 alpha-hydroxylase gene during its circadian modulation in vivo. Hepatology 21 1658-1667.

Brassil PJ, Edwards RJ \& Davies DS 1995 Expression and distribution of cholesterol 7 alpha-hydroxylase in rat liver. Biochemical Pharmacology 50 311-316.

Eilers F, Modaressi S \& Jungermann K 1995 Predominant periportal expression of the fructose 1,6-bisphosphatase gene in rat liver: dynamics during the daily feeding rhythm and starvation-refeeding cycle. Histochemistry and Cell Biology 103 293-300.

Falcone M, Miyamoto T, Fierro-Renoy F, Macchia E \& DeGroot LJ 1994 Evaluation of the ontogeny of thyroid hormone receptor isotypes in rat brain and liver using an immunohistochemical technique. European Journal of Endocrinology 130 97-106.

Feng X, Jiang Y, Meltzer P \& Yen PM 2000 Thyroid hormone regulation of hepatic genes in vivo detected by complementary DNA microarray. Molecular Endocrinology 14 947-955.

Gullberg H, Rudling M, Salto C, Forrest D, Angelin B \& Vennström B 2002 Requirement for thyroid hormone receptor $\beta$ in $T_{3}$ regulation of cholesterol metabolism in mice. Molecular Endocrinology 16 1767-1777

Jungermann K \& Katz N 1989 Functional specialization of different hepatocyte populations. Physiological Reviews 69 708-764. 
Klinger W, Devereux T \& Fouts J 1988 Separation and characterization of hepatocytes from immature and adult rats into distinct subpopulations by centrifugal elutriation. Experimental Pathology 33 213-222.

Macchia E, Falcone M, Giorgilli G, Bogazzi F, Antonangeli L, Baccarini S, Fontanini G, Torresani J, DeGroot LJ \& Pinchera A 1992 Site-specific anti-c-erb A antibodies recognizing native thyroid hormone receptors: their use to detect the expression and localization of alpha and beta c-erb A proteins in rat liver. Journal of Receptor Research 12 201-215.

Massimi M, Lear SR, Huling SL, Jones AL \& Erickson SK 1998 Cholesterol 7 alpha-hydroxylase (CYP7A): patterns of messenger RNA expression during rat liver development. Hepatology 28 1064-1072.

Ng L, Rusch A, Amma LL, Nordstrom K, Erway LC, Vennstrom B \& Forrest D 2001 Suppression of the deafness and thyroid dysfunction in Thrb-null mice by an independent mutation in the Thra thyroid hormone receptor $\alpha$ gene. Human Molecular Genetics 10 2701-2708.

Nissim-Rafinia M \& Kerem B 2002 Splicing regulation as a potential genetic modifier. Trends in Genetics 18 123-127.

Perrone-Bizzozero N \& Bolognani F 2002 Role of $\mathrm{HuD}$ and other RNA-binding proteins in neural development and plasticity. Journal of Neuroscience Research 68 121-126.

Rodd C, Schwartz HL, Strait KA \& Oppenheimer JH 1992 Ontogeny of hepatic nuclear triiodothyronine receptor isoforms in the rat. Endocrinology 131 2559-2564.

Strait KA, Schwartz HL, Seybold VS, Ling NC \& Oppenheimer JH 1991 Immunofluorescence localization of thyroid hormone receptor protein beta 1 and variant alpha 2 in selected tissues: cerebellar Purkinje cells as a model for beta 1 receptor-mediated developmental effects of thyroid hormone in brain. PNAS $\mathbf{8 8}$ 3887-3891.

Swick RW, Tollaksen SL, Nance SL \& Thomson JF 1970 The unique distribution of ornithine aminotransferase in liver mitochondria. Archives of Biochemistry and Biophysics 136 212-218.

Tagami T, Nakamura H, Sasaki S, Mori T, Yoshioka H, Yoshida H \& Imura H 1990 Immunohistochemical localization of nuclear 3,5,3'-triiodothyronine receptor proteins in rat tissues studied with antiserum against C-ERB A/T3 receptor. Endocrinology 127 $1727-1734$.

Wiersinga WM, Frank HJ, Chopra IJ \& Solomon DH 1982 Alterations in hepatic nuclear binding of triiodothyronine in experimental diabetes mellitus in rats. Acta Endocrinologica 99 79-85.

Wikstrom L, Johansson C, Salto C, Barlow C, Campos Barros A, Baas F, Forrest D, Thoren P \& Vennstrom B 1998 Abnormal heart rate and body temperature in mice lacking thyroid hormone receptor a1. EMBO Journal 17 455-461.

Yen P 2001 Physiological and molecular basis of thyroid hormone action. Physiological Reviews 81 1097-1142.

Zandieh-Doulabi B, Platvoet-ter Schiphorst M, van Beeren HC, Labruyere WT, Lamers WH, Fliers E, Bakker O \& Wiersinga WM $2002 \mathrm{TR}$ (beta) 1 protein is preferentially expressed in the pericentral zone of rat liver and exhibits marked diurnal variation. Endocrinology 143 979-984.

Received in final form 25 June 2003

Accepted 1 September 2003

Made available online as an

Accepted Preprint 8 September 2003 